Federal Reserve Bank of Minneapolis

Research Department Staff Report 428

June 2009

\title{
Superstores or Mom and Pops? Technology Adoption and Productivity Differences in Retail Trade
}

David Lagakos

Federal Reserve Bank of Minneapolis and Arizona State University

\begin{abstract}
I document that cross-country productivity differences in retail trade, which employs around $20 \%$ of workers, are accounted for in large part by compositional differences. In richer countries, most retailing is done in modern stores, with high measured output per worker, whereas in developing countries, retail trade is dominated by less-productive traditional stores. I hypothesize that developing countries rationally adopt few modern stores since car ownership rates are low. A simple quantitative model of home production supports the role of cars in determining the composition of retail technologies used and retail-sector productivity differences across countries.
\end{abstract}

*Email: lagakos@asu.edu. For guidance on this project since it began I thank Matthias Doepke, Hugo Hopenhayn, and Lee Ohanian. The paper has benefitted from the comments of many others, including Andy Atkeson, Steve Berry, Mark Bils, Paco Buera, Ariel Burstein, V.V. Chari, Allan Collard-Wexler, Alex Galetovic, Christian Hellwig, Berthold Herrendorf, Bart Hobijn, Tom Holmes, Greg Kaplan, Joe Kaboski, Narayana Kocherlakota, Jeff Lin, Igor Livshits, Ellen McGrattan, Gabriel Natividad, Guillermo Ordoñez, Richard Rogerson, Jim Schmitz, Jon Vogel, Mike Waugh, Mark Wright, and Randy Wright, plus seminar participants at ASU, Chicago GSB, the Federal Reserve Board, Iowa, Maryland, the Minneapolis Fed, NYU Stern, Penn, Rochester, UC Berkeley Haas, UCLA, UCSD, USC Marshall, Wharton, Yale, the 2007 SED in Prague, the Latin American TFP Conference at UCSB, and the 2008 NBER Summer Institute. For help with a wide variety of data sources, I thank Karin Murphy and Brooke Tosi; for help with Mexican data, I thank Marcelo Ore Vásquez and Javier Pérez Estrada; and for help with Cypriot data, I thank Alexis Antoniades and Sofronis Clerides. For editorial assistance I thank Kathy Rolfe and Joan Gieseke. The views expressed herein are those of the author and not necessarily those of the Federal Reserve Bank of Minneapolis or the Federal Reserve System. 


\section{Introduction}

Why are observed differences in per capita income across countries so large? Development accounting studies have concluded that cross-country differences in physical or human capital per worker can explain only a minor part of the observed income gaps. Instead, variations in productivity account for most of the income differences. Unfortunately, aggregate productivity is still poorly understood (Klenow and Rodríguez-Clare, 1997; Prescott, 1998; Hall and Jones, 1999). In this paper, I shed light on aggregate differences in output per worker by explaining productivity differences in one important sector, namely, retail trade.

My study of productivity differences in retail trade contributes to understanding aggregate differences for two main reasons. First, the retail sector forms a large fraction of the aggregate, employing just under $20 \%$ of all workers in a typical country. ${ }^{1}$ Thus, understanding measured output per worker in retail trade is relevant for overall productivity. Second, my results lead to new implications for why aggregate productivity differences might arise and what types of government policies keep productivity low. Specifically, I argue that low measured productivity in developing-country retail largely represents the optimal choice of technology adoption given the low income level of these countries. This is in stark contrast to arguments that low measured productivity is the result of barriers to the adoption of new technologies (Parente and Prescott, 1994), a lack of competitive pressure (Schmitz, 2005), or policies that misallocate resources across producers (Hsieh and Klenow, 2009; Restuccia and Rogerson, 2008). ${ }^{2}$

My analysis consists of two basic parts. In the first part, I use disaggregate data from censuses of retail trade to measure and account for productivity differences in the retail sectors of the United States and a set of developing countries. I show that retail-sector productivity differences are largely accounted for by compositional differences, or specifically, differences in the relative use of "modern" retail technologies, such as superstores, and "traditional" technologies, such as "mom and pop" shops. Modern stores are used widely in the United States, and much less frequently in the developing world. This is true even though, in the developing countries, measured productivity in modern stores is roughly four times higher than in traditional stores.

In the second part of my analysis, I provide a theory of these retail compositional differences. I argue that developing countries rationally adopt few modern stores since car ownership rates are low. I support this idea using new geographic evidence from the United States and Mexico showing that geographic districts with higher rates of car ownership have higher fractions of retail employment at modern stores.

\footnotetext{
${ }^{1}$ In the United States, for example, the share of private employment in retail trade has fluctuated in the range of $16 \%$ to $19 \%$ since 1975 (Bosworth and Triplett, 2004).

${ }^{2}$ Other prominent ideas in this vein include worker resistance to new production methods (Clark, 1987) and barriers to entry (Parente and Prescott, 1999; Herrendorf and Teixeira, 2009).
} 
I formalize this idea in a simple general-equilibrium model of home production in the spirit of Becker (1965) and Greenwood, Seshadri, and Yorukoglu (2005). My theory assumes that two retail technologies are freely available in all countries: highly productive modern stores and less productive traditional stores. Both stores require an input of shopping time from the households, and modern stores require a relatively larger time input. This assumption is meant to capture the fact that traditional stores are typically located in residential neighborhoods, whereas modern stores, which need more land, are usually located farther from their customers. Households trade off the lower prices at modern stores against higher shopping costs. Countries are endowed with exogenous differences in general productive efficiency, which lead to differences in average household income. Most households in developed countries, with higher income, choose to buy cars and shop at modern stores; constrained by low income, few households in developing countries buy cars, and most elect to shop at traditional stores. Entrepreneurs thus rationally choose to operate the retail technology that fits their customers: more modern stores in richer countries and more traditional stores in poorer countries. ${ }^{3}$

I parameterize the model to resemble the United States, in particular in its high modern retail shares and high car ownership rates. I then compute the model's prediction when income is lowered to Mexico's level, in order to estimate how much of the differences in retail composition can be accounted for by the theory. I find that the model explains roughly two-thirds of the differences in retail composition between the United States and Mexico, and roughly onethird of retail productivity differences. I conclude that the mechanism I have identified is an important factor in understanding differences in the structure and measured productivity of retail trade across countries.

I conclude by asking which policies affect retail productivity in developing countries. I examine some existing policies that distort car markets, and provide evidence from a natural experiment in Cyprus that relaxing restrictions on car imports increased car ownership and raised modern store prevalence. Qualitatively, consistent with the case of Cyprus, the model predicts that policies which lower car prices in developing countries would increase the number of modern stores located there and increase sector productivity. Quantitatively, I find the effects to be sizeable.

The paper suggests new implications for how economists think about measured productivity differences across countries. One implication is that developing countries may rationally choose some technologies with low measured productivity given that overall efficiency (and hence average income) is low. In this vein, my work is similar to that of Acemoglu and Zilibotti (2001) and Caselli and Coleman (2006), who argue that developing countries may optimally

\footnotetext{
${ }^{3}$ I abstract from spatial competition for simplicity, and because it allows for more transparency in the quantitative analysis. For a model of spatial competition between retail stores with the same qualitative predictions as the current paper, see Lagakos (2008).
} 
choose different technologies than richer countries. These studies differ in that they argue that poor countries may adopt different technologies because of low endowments of skilled labor, not low average income, like in my study. My work also shares some of the flavor of Jones (2009), who argues that low productivity in one sector, such as manufacturing, could be the result of inefficiencies in a complementary sector, such as electricity.

A second implication of my paper is that a broader fraction of household time and capital goods are inputs to production than previously thought, and hence some household inputs are missing from current productivity measures. In the retail trade sector, this applies to household shopping time and capital goods used for transportation and storage, such as cars. The (large) non-tradeable service sector is also likely to be affected, since households spend time and goods inputs acquiring market services. In this way, my work builds on the tradition of papers in macroeconomics that assign home production a central role in driving aggregate phenomena (for example, Benhabib, Rogerson, and Wright, 1991; Parente, Rogerson, and Wright, 2000). The work most closely related to mine is that of Buera and Kaboski (2007), who look at the role of home production in the rise of the service economy. To the best of my knowledge, my paper is the first to link home production to differences in technology adoption across countries.

\section{Retail Productivity Differences across Countries}

In this section, I document that differences in the composition of retail technologies used across countries are an important factor in accounting for measured productivity gaps in retailing. My paper is the first to use national census data to study differences in retail productivity levels between the United States and the developing world. The McKinsey Productivity Studies, discussed in detail below, provide an earlier and less formal study of these differences using their own (private) data.

\subsection{Retail Output and Labor Productivity}

I begin by describing how I measure retail productivity. The main component in measuring productivity in any economic activity is the measure of output. Conceptually, the output of a retailer is perhaps best described as "a composite bundle of services" attached to the goods being sold (Oi, 1992). This composite service is not directly measurable, however. Hence, retail output is constructed by deflating some measure of the value of retail output by an appropriate price measure.

To compute output in this way, I assume that final retail output $Y$ is a combination of two inputs: a composite service produced by the retailer and an intermediate good purchased by 
the retailer for resale, denoted $X$. Formally, the production function is

$$
Y=\min [A \cdot N, X]
$$

where $A$ is the efficiency of service production and $N$ is the labor input hired by the retailer. One might think of $X$ as a basket at goods at the factory door and $Y$ as that same basket available for purchase on the retail store shelves. I assume no substitutability between the retail services and the intermediate good purchased for resale, since it permits productivity measures using the publicly available censuses at my disposal and since the assumption seems to be fairly standard in retail productivity measurement; the U.S. Bureau of Economic Analysis (BEA) makes this assumption when measuring retail-sector value added, for example. ${ }^{4}$

\subsection{Using New Censuses of Retail Trade}

To measure retail productivity, I use new data from censuses of retail trade that I collected for a set of developing countries. The set includes every developing country in which a census of retail establishments has been conducted in the last 10 years, and for which international comparisons could be made. ${ }^{5}$ In Appendix A I provide more detail about the censuses. I end up with data from Brazil (2002), El Salvador (2004), Mexico (2003), the Philippines (2005), and Thailand (2002). For comparisons, I also draw on data from the United States for the same years as the foreign censuses, using retail-sector data from the BEA.

The censuses provide comparable measures of labor input, the value of sales, and the cost of goods purchased for resale, by size category of retail establishment. To facilitate international comparisons, I express all nominal quantities in international dollars, which are adjusted for purchasing power parity (PPP) using the consumption price deflator from the Penn World Tables. The motivation for this choice of deflator is that the price of the goods sold at retail should be reasonably proxied by the price of consumption goods paid by households.

I measure labor productivity in each country for three segments of retail establishments, namely, the modern stores $(M)$, the traditional stores $(T)$, and the retail sector as a whole $(R)$. I define modern establishments to be those with 20 or more workers. This definition allows a reasonable proxy for stores using advanced inventory and distribution techniques, and maximal compatibility across countries. Traditional stores are therefore those with fewer than 20 workers. ${ }^{6}$

\footnotetext{
${ }^{4}$ Furthermore, the North American Industrial Classification System (NAICS), used to construct my U.S. data, defines the retail trade sector as "establishments engaged in retailing merchandise, generally without transformation," implying a separation between producing the goods themselves and the services added to sell them.

${ }^{5}$ I thank Karin Murphy and Brooke Tosi of the Minneapolis Federal Reserve Bank Research Library for their invaluable help with this search.

${ }^{6}$ Size cutoffs of $10+$ or $50+$ workers produce similar results as the ones I present below in the countries that permit these cutoffs. Results for these measures are available on request.
} 
For country $i$ and segment $j \in\{M, T, R\}$, I express labor productivity relative to the U. S. retail sector as a whole (since disaggregate U.S. data are not available). Let $Y_{i, j}$ and $N_{i, j}$ be output and labor input in country $i$ and segment $j$, and let $Y_{U S, R}$ and $N_{U S, R}$ be output and labor input in the U.S. retail sector as a whole. Using the production function in (1), relative labor productivity can then be written as

$$
\frac{Y_{i, j} / N_{i, j}}{Y_{U S, R} / N_{U S, R}}=\frac{A_{i, j}}{A_{U S, R}}=\frac{p_{i, j} Y_{i, j} / N_{i, j}}{p_{U S, R} Y_{U S, R} / N_{U S, R}} \cdot \frac{p_{U S, R} Y_{U S, R} / p_{x} Y_{U S, R}}{p_{i, j} Y_{i, j} / p_{x} Y_{i, j}},
$$

where $p_{i, j} Y_{i, j}$ and $p_{x} Y_{i, j}$ are sales and the cost of goods purchased for resale in country $i$, segment $j$. This ratio represents the real quantity of services produced per worker in country $i$, sector $j$, relative to the U. S. retail sector.

\subsection{Retail Productivity Low in Developing Countries...}

Figure 1 shows the computations for labor productivity for the retail sector as a whole in each country. The U. S. retail sector is normalized to 100. The figure shows that the set of developing countries all have productivity on the order of one-third of the U. S. level. Brazil and Thailand are the highest, with $36 \%$ and $35 \%$ of the U. S. level, and El Salvador, Mexico, and the Philippines are somewhat lower, at $28 \%, 30 \%$ and $21 \%$, respectively.

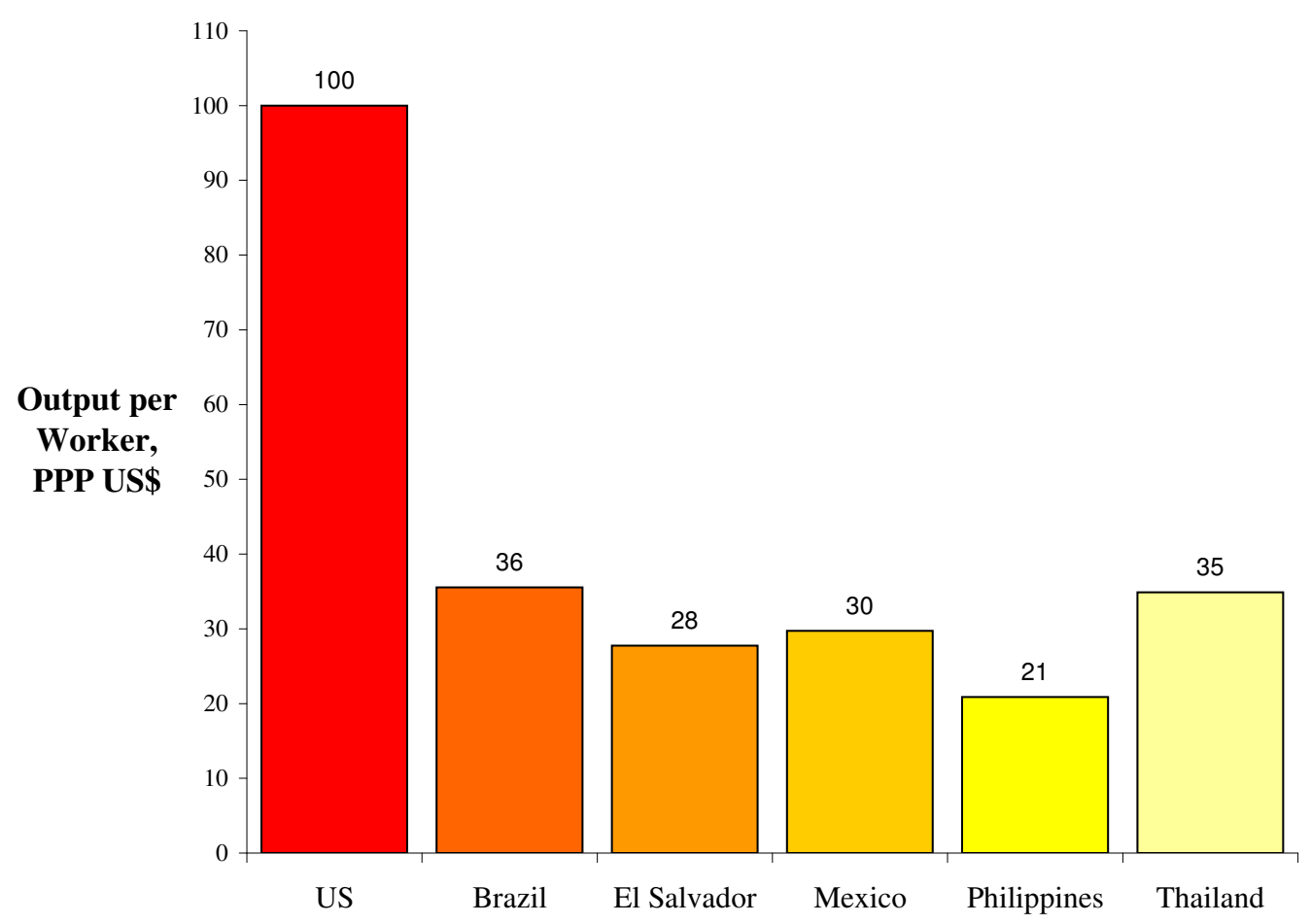

Figure 1: Retail-Sector Productivity in the United States and Developing Countries 
The results suggest that the retail-sector productivity gaps largely mimic those of the aggregate, with large productivity differences separating the United States from the developing world. According to the Penn World Tables, in the same years as the retail census discussed here, per capita incomes in PPP dollars compared to the United States were: Brazil (20\%), El Salvador (13\%), Mexico (23\%), the Philippines (11\%), and Thailand (20\%). At least among this set of developing countries, countries with lower per capita GDP tend to have lower output per worker in retail trade. But most importantly, retail productivity is much lower in these developing countries than in the United States.

\section{4 ... And Higher in Modern Stores, Even in Developing Countries}

I now use the disaggregate data to shed light on what is driving these large sectoral productivity differences.

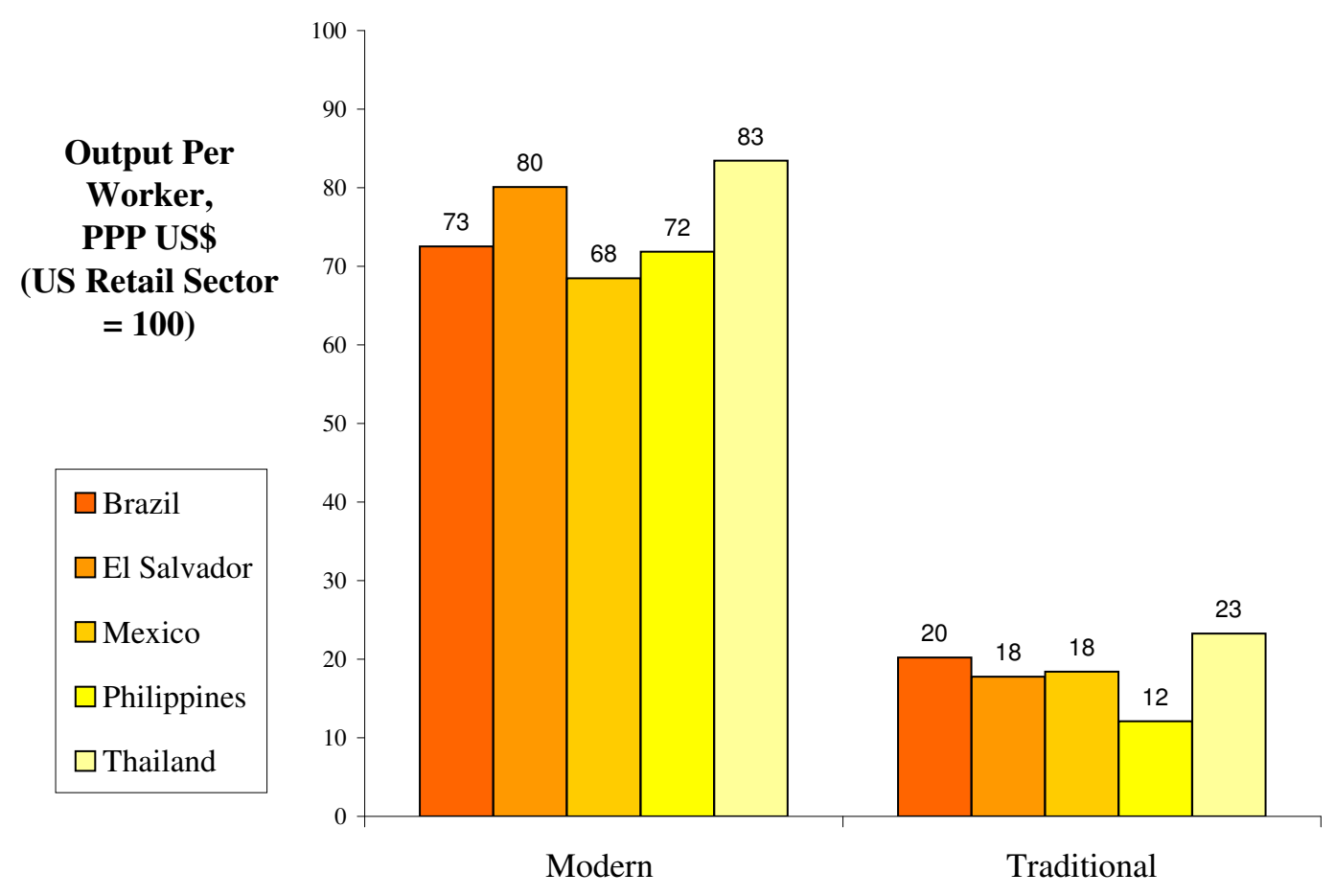

Figure 2: Labor Productivity in Modern and Traditional Stores

Figure 2 shows labor productivity by retail segment, with the U. S. retail sector as a whole again normalized to 100. The most dramatic feature to note is that productivity in modern stores is much higher than in traditional stores. Modern stores range from $68 \%$ to $83 \%$ of the U. S. level, whereas traditional stores range from $12 \%$ to $23 \%$. On average, labor is 4.3 times more productive in modern stores than in traditional stores, with Brazil, Mexico, and Thailand around 3.7 times, El Salvador at 4.4 times, and the Philippines highest at 6.0 times more productive. 
The second noteworthy feature is that modern productivity in these countries appears fairly high relative to the United States, at an average of $75 \%$ of the U. S. level. This feature is perhaps surprising given the much larger gaps in the retail sector as a whole. One possible explanation for this phenomenon is that many modern stores in the developing world are in fact operated by European or U.S. chains. For example, the French retailer Carrefour has extensive operations in Brazil, and Wal-Mart is the leading retailer in Mexico. Since the census data do not allow separation by domestic ownership status, it remains an open question whether the high productivity of modern stores is driven by foreign participants. A separate but related question is how modern and traditional stores in the United States compare to their counterparts in the developing countries. Publicly available data for the United States preclude these calculations as well. According to the McKinsey Productivity Studies (described in Appendix A), productivity in modern stores is on average $70 \%$ as high in the developing countries as modern stores in the United States, and for traditional stores, productivity is on average $55 \%$ of that in the United States.

One key question is whether these labor productivity differences can be accounted for by differences in capital or land per worker. Although limited data on capital preclude calculations for the entire set of developing countries, in Appendix A I use data from Mexico to construct Total-Factor Productivity (TFP) measures by retail segment. I conclude that labor productivity differences between Mexico and the United States largely represent TFP differences.

\subsection{Few Modern Stores in Developing Countries}

Having computed productivity differences by type of store, I now turn to the question of how frequently each type is used. Figure 3 shows the percentage of retail trade employment in each type of store, with the two bars for each country summing to $100 \%$. The large compositional differences are immediately apparent. In the United States, $67 \%$ of retail employment is in modern establishments and just $33 \%$ is in traditional stores. ${ }^{7}$ In each of the developing counties, in contrast, modern stores employ around $20 \%$ of all retail workers. It is also perhaps surprising how uniform the modern shares are, with a low of 15\% in El Salvador and the Philippines and highs of just $21 \%$ and $23 \%$ in Brazil and Mexico.

The figure suggests a prominent role for differences in modern employment shares in explaining retail-sector output-per-worker differences, especially given that labor productivity is around four times higher in modern stores, as shown in the previous section.

\footnotetext{
${ }^{7}$ Modern stores seem to dominate retailing in Western Europe as well. According to Baily and Solow (2001, p. 165, Table 5), modern retailers constitute $70-75 \%$ of total retail sales in Germany, France, the United Kingdom, and the Netherlands, compared to around $85 \%$ of sales in the United States.
} 


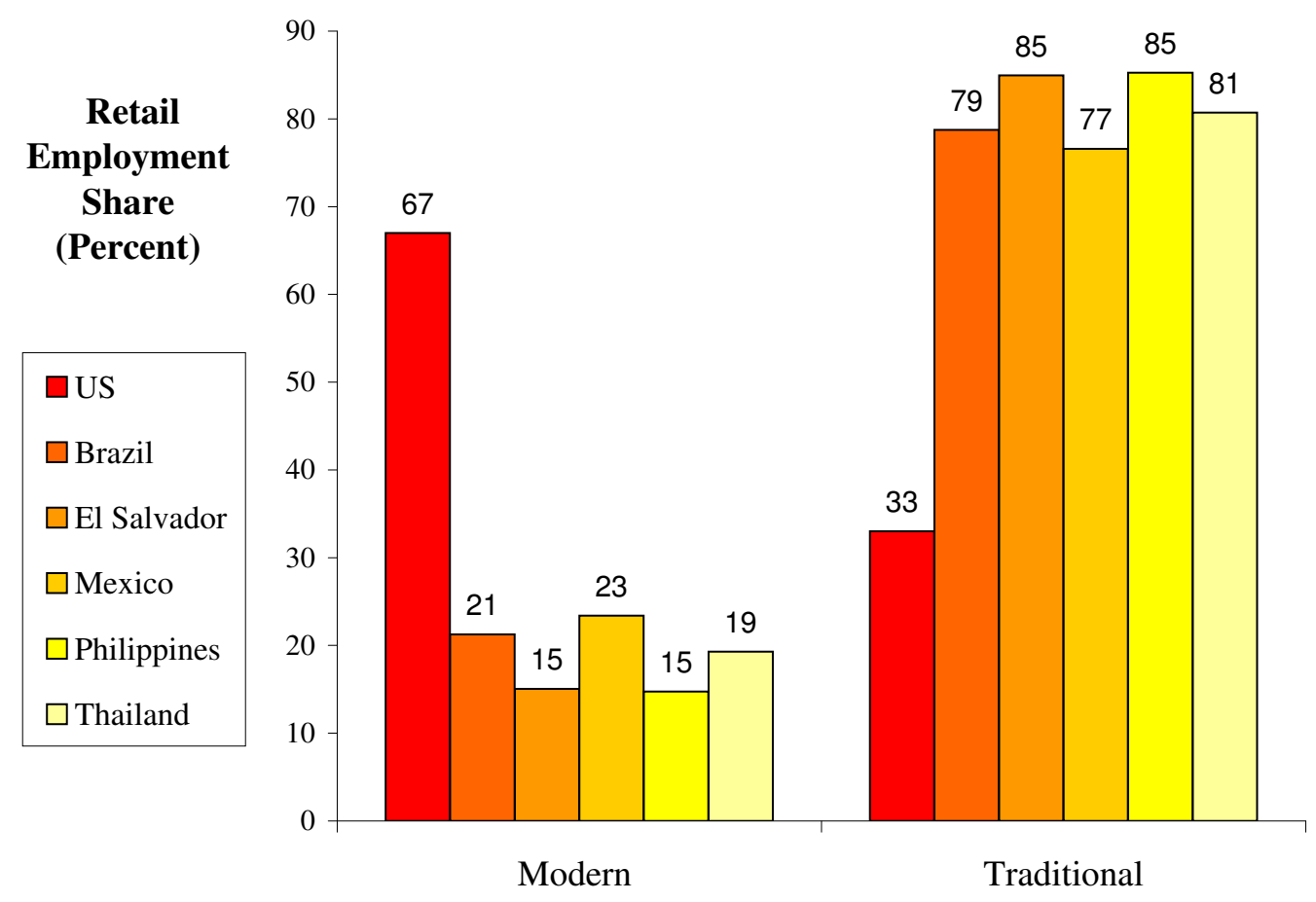

Figure 3: Employment Shares in Modern and Traditional Stores

\subsection{Composition Important for Retail Productivity Differences}

The results thus far suggest that differences in the composition of retail technologies used are central in accounting for measured productivity differences in the retail sector as a whole. I conclude this section by formally quantifying the role of composition. For each country studied, I ask how much higher output per worker would be under the United States retail composition, holding fixed the productivity levels of the two technologies.

The first data column of Table 1 shows the actual productivity levels for the sector as a whole (as in Figure 2), with labor from $21 \%$ to $36 \%$ as productive as the United States. The second column shows what labor productivity would be hypothetically in each country under the United States's composition, namely, $67 \%$ of employment in modern stores. For each country, the hypothetical productivity level would be above one-half the U. S. level, in the range of $52 \%$ to $64 \%$. The third column reports the ratio of hypothetical to actual productivity. The ratios range from 1.5 to 2.5 with an average of 1.95 , implying that productivity would roughly double in these countries if they were to use the United States mix of technologies. The fourth column reports the percentage of the gap between the country and the United States that is closed under this experiment. The findings show a closing in the range of $31 \%$ to $44 \%$ of the productivity differential. The analysis implies more formally what the graphs earlier suggest, namely, that labor productivity differences in retail trade are accounted for in large part by composition differences. 


\begin{tabular}{|c|c|c|c|c|}
\hline \multirow[t]{2}{*}{ COUNTRY } & \multicolumn{2}{|c|}{ RETAIL SECTOR Y /N } & \multirow{2}{*}{$\begin{array}{c}\text { RATIO OF } \\
\text { HYPOTHETICAL } \\
\text { TO ACTUAL } \\
\text { Y/L }\end{array}$} & \multirow{2}{*}{$\begin{array}{c}\text { \% OF GAP } \\
\text { With UNited StATES } \\
\text { ClOSED }\end{array}$} \\
\hline & ACTUAL & $\begin{array}{c}\text { UNDER UNITED STATES } \\
\text { MODERN SHARE }\end{array}$ & & \\
\hline Brazil & 36 & 55 & 1.52 & 31 \\
\hline El Salvador & 28 & 60 & 2.14 & 44 \\
\hline Mexico & 30 & 52 & 1.73 & 32 \\
\hline Philippines & 21 & 52 & 2.50 & 40 \\
\hline Thailand & 35 & 64 & 1.82 & 44 \\
\hline
\end{tabular}

Note: Labor productivity in the United States retail sector is normalized to 100.

Table 1: Retail Composition and Productivity Differences

These composition differences seem to have played a central role in explaining retail productivity gains in recent U. S. history as well. Foster, Haltiwanger, and Krizan (2006) show that virtually all the labor productivity gains in retail trade over the 1990s are accounted for by more productive retail establishments replacing less productive ones. Furthermore, the stores being replaced were mostly small, independent establishments, and most of the expansion was in large-scale modern stores.

\section{An Explanation for the Differences}

The findings thus far suggest that differences in the adoption of modern stores are a key factor in accounting for retail productivity differences across countries. Poorer countries could double their measured output per worker in retail trade by using the United States composition rather than their own. So why don't they? In this section, I present one theory for these composition differences. For expositional purposes, I relegate the discussion of other candidate explanations to Appendix B.

In short, my theory is as follows. Because of their large scale of operation, modern stores must locate farther than traditional stores from residential centers in order to operate. Cars and other durable goods, such as refrigerators and spacious houses, allow households to reduce shopping time at modern stores by cutting down on travel time per trip as well as the number of shopping trips. Households without these complementary durable goods find themselves with high time 
costs of doing their shopping at modern stores. Since households in poor countries elect to buy fewer of these durable goods (because of their low income), fewer modern stores operate.

I focus on cars in this paper for simplicity and because there is evidence that, unlike cars, refrigerators are fairly common in many developing counties. According to 2000 Census data from the Integrated Public Use Microdata Series International (IPUMS-I), household refrigerator ownership rates were 70\% in Mexico and 83\% in Brazil, compared to car ownership rates of just $32 \%$ and $34 \%{ }^{8}$

The important role of cars in limiting large-scale stores has received ample attention in the literature on retailing in developing countries. Bromley (1998) typifies the view of this literature when, in her study of Latin American retailing, she argues that

the pattern of retail space in the Latin American city reflects some powerful influences of consumer behavior. Low mobility constrains most consumers to patronising traditional retail facilities which can be reached by foot or bus, whilst the small, affluent car-owning sector of the population comprises the principal clientele of the modern supermarket and planned shopping centres. ${ }^{9}$

\subsection{Modern Stores Located Mostly in Areas with Cars}

In this section, I provide some new geographic evidence that further supports the role of cars in limiting the widespread adoption of modern stores. I focus on Mexico and the United States, since economic and household census data are collected for these countries at a low (and comparable) level of geographic disaggregation. ${ }^{10}$ The modern retail share in the United States is the fraction of retail employees at establishments with 20 or more employees. In Mexico, the modern share is the fraction of food retail employees at supermarkets, which is the best proxy available by county (municipio).

To support my theory that low car ownership explains some of the developing countries' reliance on traditional stores, the data should show a positive relationship among car ownership

\footnotetext{
${ }^{8}$ Historical studies on the rise of modern retailing in the United States have also emphasized the role of cars and household durables more broadly (Fuchs, 1969; Oi, 1992). In recent paper, Kopecky and Suen (2008) explore the role of cars in the suburbanization of the United States.

${ }^{9}$ Similarly, in his study of retailing in China, Goldman (2000) argues that although "appropriate sites [for modern stores] are more easily available in the outlying areas, these areas are sparsely populated and large-scale stores there will need to draw customers from larger distances. However, since the ownership of motorized vehicles (cars or motorcycles) is very limited, this is not feasible at present."

${ }^{10}$ For the United States, I use the 2000 Census of Population and 2004 County Business Patterns data to construct county-level measures of median household income, average household car ownership, and the fraction of retail employment in modern stores. For Mexico, I use the 2000 Mexican Census of Population and the 2004 Censo Económico, constructed by the Instituto Nacional de Estadistíca, Geografía e Informática (INEGI). All data are publicly available at www.inegi.gob.mx/inegi/default.aspx. I obtain the census data from I-IPUMS. Income in both countries is measured as the median household income expressed in 2000 PPP dollars.
} 


\begin{tabular}{|c|c|c|c|c|c|}
\hline \multirow[t]{2}{*}{ COUNTRY } & \multirow[t]{2}{*}{ VARIABLE } & \multicolumn{4}{|c|}{ Percentile of County Income Distribution } \\
\hline & & $0-25$ & $25-50$ & $50-75$ & $75-100$ \\
\hline \multirow{3}{*}{ Mexico } & Median Household Income & $\$ 4,062$ & $\$ 8,075$ & $\$ 11,606$ & $\$ 19,024$ \\
\hline & Car Ownership Rate & 0.15 & 0.27 & 0.36 & 0.49 \\
\hline & Modern Retail Share & 0.02 & 0.09 & 0.24 & 0.37 \\
\hline \multirow{3}{*}{ United States } & Median Household Income & $\$ 32,343$ & $\$ 39,852$ & $\$ 45,059$ & $\$ 59,054$ \\
\hline & Car Ownership Rate & 0.86 & 0.88 & 0.90 & 0.94 \\
\hline & Modern Retail Share & 0.58 & 0.66 & 0.69 & 0.71 \\
\hline
\end{tabular}

Table 2: Modern Retail Shares within the United States and Mexico

and share of retail workers at modern stores. That is indeed what they show. Table 2 summarizes the values of these variables by percentile of the county income distribution. As can be seen in Mexico, counties with the highest average income have car ownership rates and modern retail shares substantially higher than counties with lower income. The richest quartile of counties has a $49 \%$ car ownership rate and a modern share of $37 \%$. The poorest quartile, in contrast, has a car ownership rate of $15 \%$ and a modern share of just $2 \%$. These findings provide evidence that areas in a developing country with high modern store shares are also areas with high car ownership, and vice versa. The pattern appears prominently in the United States as well, with a lot less variation across county groups in car ownership and modern store presence. $^{11}$

The United States' data are useful in supporting the cars theory in two ways. First, they confirm that modern stores are widespread across the county income distribution, just like cars. Second, and more interestingly, they help provide some evidence that variation in modern retail shares is related to auto ownership itself, as opposed to some other factor related to income. In the United States, substantial variation can be found in median household income across counties, with a factor of 1.8 separating the lowest quartile from the highest. Car ownership exhibits much less variation, with a range of just 0.86 to 0.94 . The fact that modern retail shares also exhibit little variation within the United States - like cars and unlike income - swings the pendulum toward cars, rather than some other factor working through income.

\footnotetext{
${ }^{11}$ I also have found evidence that this pattern holds in Peru. Details are available upon request.
} 


\section{Model of Retail Technology Adoption}

I now formalize the idea outlined above that household car ownership prevalence determines the composition of retail technologies used, and hence measured retail productivity.

\subsection{Household Preferences and Technology}

The economy is populated by a unit measure of households that have preferences over consumption goods $(c)$, automobiles $(a)$, and leisure time. Households are endowed with one unit of time, spend $\bar{n}$ units of time working (inelastically, for simplicity), and spend $n_{s}$ units of time shopping for consumption goods (which they choose). Households vary in two dimensions: the value of their leisure time, and their human capital level, which affects the efficiency of one unit of their labor. Preferences of household $i$ are given by

$$
U_{i}=\log (c)+\psi_{i} \log \left(1-\bar{n}-n_{s}\right)+\alpha \cdot a,
$$

where $\psi_{i}$ is household $i^{\prime}$ 's value on leisure, $\alpha$ is the utility of having a car, and $a \in\{0,1\}$ captures car ownership, with $a=1$ if and only if the household owns a car. One can think of $\alpha$ as capturing the direct flow of utility from "Sunday drives" or commuting services, distinct from its value as a shopping device. The $\psi_{i}$ are drawn from some distribution $H(\cdot)$ with non-negative support, and represent taste differences in leisure activities versus consumption goods.

As in Becker (1965), I assume the final consumption good is "produced" by the household by combining market goods $(y)$, household shopping time $\left(n_{s}\right)$, and possibly an auto $(a)$. One can think of $y$ as a basket of the composite consumption good on the store shelves and $c$ as that same basket in the kitchen cupboard. To turn $y$ into $c$, the household must spend time shopping, possibly using the car. ${ }^{12}$ The household may elect to shop at either modern (M) or traditional (T) retail segments (explained further below). Formally, let $j \in\{M, T\}$ denote the segment type, and let the home production function for final consumption goods from a type- $j$ retailer be denoted $C_{j}\left(y_{j}, n_{s, j}, a\right)$. Total consumption is given by

$$
c=C_{M}\left(y_{M}, n_{s, M}, a\right)+C_{T}\left(y_{T}, n_{s, T}, a\right)
$$

There is a fixed shopping time cost for the household that varies by retail segment, denoted $\nu_{j}$. Shopping at the modern segment requires a relatively larger time cost, that is, $\nu_{M}>\nu_{T}$. This assumption is a crude but tractable way of capturing the friction associated with modern retail stores, namely, that their larger scale of operations forces them to locate farther from the typical

\footnotetext{
${ }^{12}$ This specification is akin to the home production models of Greenwood, Seshadri, and Yorukoglu (2005), and Buera and Kaboski (2007) in that durable goods facilitate household consumption.
} 
household and hence requires a larger input of a household's travel time in order for market transactions to occur. ${ }^{13}$ Formally, the shopping production function is given by

$$
C_{j}\left(y_{j}, n_{s, j}, a\right) \equiv \begin{cases}y_{j} & \text { if } n_{s, j} \geq \gamma \cdot \nu_{j} \text { and } a=1 \\ y_{j} & \text { if } n_{s, j} \geq \nu_{j} \text { and } a=0 \\ 0 & \text { otherwise }\end{cases}
$$

where the parameter $\gamma \leq 1$ represents the time savings by shopping with a car. This production function says simply that in order for the household to consume, it must pay for the consumption goods and spend time shopping and transporting the goods home. The car cuts down on the required shopping time at either retail segment. This can be thought of as arising from faster travel time per trip as well as economizing on the number of shopping trips.

Finally, the budget constraint for household $i$ is given by

$$
\eta_{i} \bar{n} w \geq p_{a} a+p_{T} y_{T}+p_{M} y_{M},
$$

where $\eta_{i}$ is the human capital of household $i$ and $w$ is the wage per unit of human capital. The $\eta_{i}$ terms are drawn from some distribution $G(\cdot)$ with non-negative support and are independent of $H(\cdot)$, the distribution of household leisure values. Heterogeneity in human capital will lead to a distribution of wages in the economy and hence heterogeneity in the car ownership decision.

\subsection{Market Production}

Market production is done in two distinct sectors: the intermediate goods sector and the retail sector. Production technologies in both sectors are operated by perfectly competitive entrepreneurs, and there is unrestricted access to any production technology. The intermediate goods sector produces a composite good $X$ using a constant-returns technology

$$
X=E \cdot N
$$

where $E$ denotes general efficiency of production in the economy, and is meant to be thought of as the primitive of a given country. Intermediates may either be turned into retail goods by being combined with retail services (described below) or be turned into cars. A car may be produced from $\bar{A}$ units of intermediates.

\footnotetext{
${ }^{13}$ For a spatial model that captures this friction more explicitly see Lagakos (2008). Abstracting from space maintains the qualitative predictions of that model while allowing more transparency in the quantitative analysis that follows in the subsequent section.
} 
The retail sector produces retail services and then combines these services with the intermediate goods to produce a final output $Y$ that households may purchase. Two different retailing technologies are available: modern and traditional, each of which uses labor to produce retail services. The two technologies are best thought of as representing the output of a retail segment, or aggregate of stores in each technology type, rather than the output of a particular store. Letting $j \in\{M, T\}$ index the technology type, the production function is given by

$$
Y_{j}=\min \left[E \cdot Z_{j} \cdot N_{j}, X\right],
$$

where $E \cdot Z_{j}$ is the efficiency of labor in producing retail services. This comprises general efficiency, $E$, times retail-technology-specific efficiency, $Z_{j}$. Of the two technologies, the modern one is more efficient at providing retail services; that is, $Z_{M}>Z_{T}$.

\subsection{Stages of Production}

Summarizing the stages of production of the final consumption good described above is helpful. Figure 4 summarizes these stages.

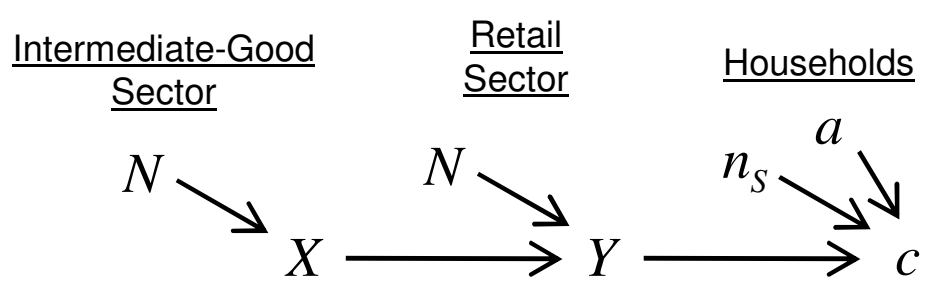

Figure 4: Stages of Production

The intermediate goods sector uses labor to produce $X$, a good at the factory door. Next, the retail sector combines $X$ with labor to produce $Y$, a good on the store shelf. Finally, a household combines shopping time (possibly with a car) and store-bought goods $Y$ to produce $c$, a good in the kitchen cupboard, which the household can consume.

\subsection{Optimization and Market Clearing}

Household optimization consists of two discrete choices: where to shop and whether to buy a car. Intuitively, since cars are superior goods in the utility function, buying one is optimal only when income is sufficiently high. As for the choice of where to shop, because goods are perfect substitutes as final consumption, households will go to a corner and do all their purchases at 
one of the two retail segments. The key trade-off that households face is one of time savings versus cost savings. Shopping at the modern store takes more time but offers lower prices.

Optimal household behavior is most easily understood in a world without heterogeneity in human capital or time value. In such a world, all households choose to buy a car if and only if $E$ is sufficiently high. Regarding the choice of where to shop, one of three cases is possible (depending on parameters). First, households shop at the traditional segment regardless of whether they have a car. Second, households shop at the modern segment whether or not they have a car. Third, and most interestingly, they shop at the modern segment if and only if they have a car. In this third case, one can see the model's main result cleanly. When $E$ is sufficiently high, all households buy cars and shop at modern stores. Otherwise, when $E$ is low, no one owns a car and no households shop at modern stores. The choice of which retail technology is used is driven entirely by optimal household behavior given $E$.

Although transparent, the homogeneous world is not suitable for quantitative analysis, since household optimization implies that the economy uses either all modern stores or none. To get predictions for the (empirically relevant) case of modern store shares between 0 and 1 , we must return to the model with heterogeneity. In this case, optimal behavior is as follows.

Proposition 1 For a household with human capital $\eta_{i}$ and time value $\psi_{i}$, purchasing a car is optimal if and only if

$$
\eta_{i} \geq \tilde{\eta}(\psi) \equiv \frac{p_{A}}{\bar{n} w(1-\chi(\psi) \exp (-\alpha))},
$$

where

$$
\chi(\psi) \equiv \begin{cases}\left(\frac{1-\bar{n}-\nu_{M}}{1-\bar{n}-\gamma \nu_{M}}\right)^{\psi} & \text { if } \psi \leq \tilde{\psi}(0) \\ \left(\frac{p_{M}}{p_{T}}\right)\left(\frac{1-\bar{n}-\nu_{T}}{1-\bar{n}-\gamma_{M}}\right)^{\psi} & \text { if } \tilde{\psi}(0)<\psi \leq \tilde{\psi}(1) \\ \left(\frac{1-\bar{n}-\nu_{T}}{1-\bar{n}-\gamma \nu_{T}}\right)^{\psi} & \text { if } \psi>\tilde{\psi}(1) .\end{cases}
$$

Shopping in the modern segment is optimal if and only if

$$
\psi_{i} \leq \tilde{\psi}(a)=\frac{\log \left(\frac{p_{T}}{p_{M}}\right)}{\log \left(\frac{1-\bar{n}-a \gamma \nu_{T}-(1-a) \nu_{T}}{1-\bar{n}-a \gamma \nu_{M}-(1-a) \nu_{M}}\right)},
$$

given car ownership status $a \in\{0,1\}$.

Figure 5 illustrates the household's optimal behavior characterized in Proposition 1. Each household is represented as an element of the plane, with the $x$-axis representing $\psi_{i}$ and the $y$-axis representing $\eta_{i}$. It helps to divide the households into three groups based on their time value $\psi_{i}$. The modern-only households are those with relatively low values of $\psi_{i}$, satisfying 


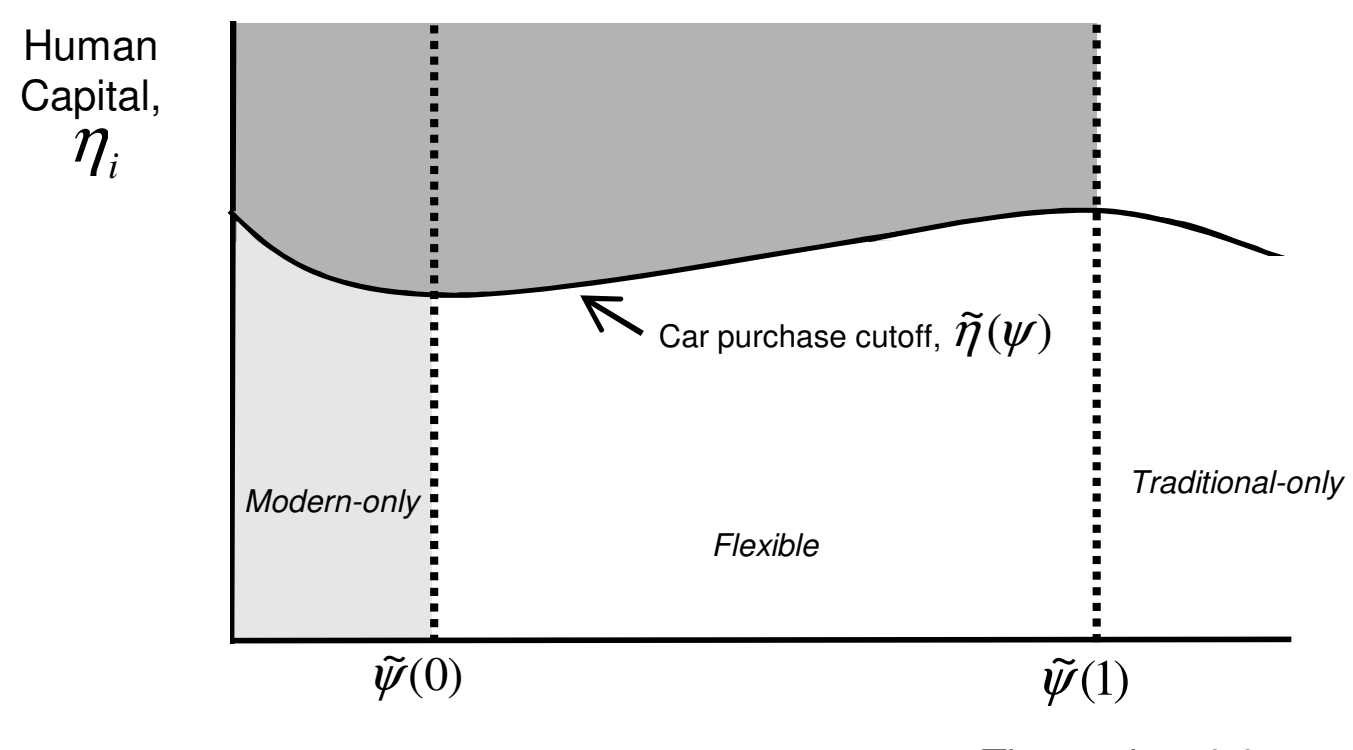

Time value, $\psi_{i}$

Figure 5: Solution to the Households' Problem

$\psi_{i}<\tilde{\psi}(0)$, and shop at modern stores whether or not they have a car. The flexible households, for lack of a better term, have $\psi_{i}$ satisfying $\tilde{\psi}(0) \leq \psi_{i}<\tilde{\psi}(1)$, and shop at modern stores if and only if they purchase a car. Finally, the traditional-only households have relatively high values of $\psi_{i}$, satisfying $\psi_{i} \geq \tilde{\psi}(1)$. The shaded portion of the figure describes the set of households that shop at modern stores, with the darker region representing those that come by car. ${ }^{14}$

One important feature of the model is that a household's human capital level does not affect its choice of where to shop (over and above the car purchase decision). In other words, the cutoffs $\tilde{\psi}(a)$ do not depend on $\eta_{i}$. Households with higher human capital have a higher opportunity cost of shopping time in terms of wage income, but this cost is exactly offset by the decreasing marginal utility of additional goods purchased with those wages. The balanced growth preferences which drive this feature of the model were assumed in order to match the observation of roughly constant shopping time over the income distribution in the cross section of U.S. households. ${ }^{15}$

Turning to the producers' problems, it is simplest to let $X$ be the numeraire. Since markets are perfectly competitive, the wage must satisfy $w=E$, and retail prices must satisfy $p_{M}=1+1 / Z_{M}$ and $p_{T}=1+1 / Z_{T}$. Notice that prices are lower in modern stores than in traditional stores. The auto price must be $p_{a}=\bar{A}$. Firm optimization is consistent with any quantity of labor hired;

\footnotetext{
${ }^{14}$ The non-linearity of the car purchase decision in $\psi$ is reconciled as follows. For modern-only households and traditional-only households, $\tilde{\eta}(\psi)$ is decreasing in $\psi$ because as $\psi$ rises, households value more highly the time savings from having a car. For flexible households, as $\psi$ rises, the time savings of the traditional store make shopping at the modern store with a car a less attractive option. Hence, the value of a car decreases with $\psi$.

${ }^{15}$ According to my calculations from the 2003 American Time Use Survey (ATUS), the correlation of income and shopping time is 0.02 .
} 
the household side (along with the efficiency parameters $E, Z_{M}$, and $Z_{T}$ ) determines the mix of employment in the intermediate sector and two retail segments.

Finally, an equilibrium of the model occurs when all agents optimize, and the five markets clear. These are the labor market, the market for intermediate goods, the car market, and the modern and traditional retail markets. For brevity, the equations behind these conditions are omitted.

\subsection{Retail-Sector Composition and Productivity}

I now turn to how productivity in retail is measured and determined in equilibrium. Let $Y_{R} \equiv$ $Y_{M}+Y_{T}$ be total retail output and $N_{R} \equiv N_{M}+N_{T}$ represent total retail employment. The modern retail share is denoted $\mu$ and given by

$$
\mu=\frac{N_{M}}{N_{M}+N_{T}} .
$$

Using this definition, I can write retail-sector productivity as

$$
Y_{R} / N_{R} \equiv \frac{Y_{M}+Y_{T}}{N_{M}+N_{T}}=\mu \cdot E \cdot Z_{M}+(1-\mu) \cdot E \cdot Z_{T}
$$

using (8). This expression allows one to see clearly how composition affects overall productivity: since $Z_{M}>Z_{T}$ by assumption, an economy with a higher modern retail share $\mu$ will have a higher value for $Y_{R} / N_{R}$. The main comparative static of the paper is that, with one restriction on parameters (discussed below),

Proposition 2 The modern retail share, $\mu$, is increasing in $E$ and increasing in the mean of the human capital distribution.

Proposition 2 says that an increase in $E$ induces more households to buy cars since average income is now higher and, as a result, a higher fraction of households shop in the modern segment, thereby raising $\mu$. A similar result holds when the human capital distribution shifts up. The condition on parameters is, loosely speaking, that the auto price is not too high. In Appendix C I demonstrate that if $\bar{A}$ is not sufficiently high relative to average income, then $\mu$ is strictly increasing in $E$. Intuitively, the restriction assures that the increase in expenditure at modern stores coming from flexible households that switched from traditional to modern is not outweighed by the value of cars now purchased by modern-only households, who each divert $p_{a}$ out of their expenditure at modern stores. 


\section{Quantitative Analysis}

In this section, I assess the quantitative importance of car ownership rates on retail composition. I first parameterize the model to match features of the U.S. economy in 2000, including its high modern store share and high car ownership rate. I then ask how much lower the modern share would be under Mexico's income level. I find that the model predicts roughly two-thirds the modern share differences between the United States and Mexico, and makes predictions for Mexican car ownership and other variables that are in line with Mexican data.

\subsection{Parameterization of Model Economy}

I first present an overview of how the model is parameterized to the 2000 U. S. economy. Appendix $C$ provides a more detailed description of how each parameter value is selected.

I begin by picking a functional form for the distributions of human capital and time value, $G(\eta)$ and $H(\psi)$. I set both to be lognormal, with first and second moments $\phi_{\eta}$ and $\sigma_{\eta}$ for $G(\cdot)$ and $\phi_{\psi}$ and $\sigma_{\psi}$ for $H(\cdot)$. That makes 13 parameters for which values must be chosen, including the 4 just described. The other 9 are the work time and shopping variables $\left(\bar{n}, \nu_{M}\right.$, and $\left.\nu_{T}\right)$; the car cost, value, and time savings parameters $(\bar{A}, \alpha$, and $\gamma)$; and the market technology parameters $(E$, $Z_{M}$, and $Z_{T}$ ). Table 3 below summarizes the parameter value choices and their interpretations.

Briefly, the parameter values are selected as follows. I normalize $E=1$ and choose $\phi_{\eta}$ and $\sigma_{\eta}$ to match the mean and variance of the $2000 \mathrm{U}$. S. income distribution, which are $\$ 63,950$ and $\$ 70,712$. Roughly speaking, $\phi_{\psi}$ controls the share of employment at modern stores, which I match to be 0.67 as per the findings of Section 2, and $\sigma_{\psi}$ controls the conditional probability that a shopper at a modern store came via car, which I match to 0.97 as found by the retail literature. I set $\bar{n}$ to be $1 / 3$ to represent eight hours of market work per day, and set $\bar{A}$ to match a $\$ 5,500$ yearly cost of operating a car (according to the American Automobile Association). I choose $\alpha$ to give a $91 \%$ car ownership rate, which is consistent with data from the 2000 U. S. census. For $\gamma$ I choose a value of 0.66 , which is consistent with evidence on the time savings from commuting by car versus commuting by public transportation. I pick $\nu_{M}$ and $\nu_{T}$ to be consistent with average shopping times for households with and without cars, using data from the ATUS. Finally, I set $Z_{T}$ and $Z_{M}$ to make modern stores three times as productive as traditional stores, broadly consistent with the findings of Section 2, and to make the share of aggregate employment in retail trade equal to $14 \%$, as in the United States in 2000. 


\begin{tabular}{c|c|c|l}
\hline \hline & PARAMETER & VALUE & INTERPRETATION \\
\hline \hline & & & \\
1 & $E$ & 1.00 & General efficiency of production \\
2 & $\phi_{\eta}$ & 0.25 & Mean of log human capital distribution \\
3 & $\sigma_{\eta}$ & 0.89 & Standard deviation of log human capital distribution \\
4 & $\phi_{\psi}$ & 1.86 & Mean of log time value distribution \\
5 & $\sigma_{\psi}$ & 0.29 & Standard deviation of log time value distribution \\
6 & $\bar{n}$ & 0.33 & Time spent working \\
7 & $\alpha$ & 0.51 & Taste parameter for cars \\
8 & $\bar{A}$ & 0.06 & Cost of a car \\
9 & $\gamma$ & 0.66 & Shopping time savings from car ownership \\
10 & $\nu_{M}$ & 0.04 & Shopping time at modern segment without a car \\
11 & $\nu_{T}$ & 0.01 & Shopping time at traditional segment without a car \\
12 & $Z_{T}$ & 2.62 & Efficiency of production at traditional retail segment \\
13 & $Z_{M}$ & 7.86 & Efficiency of production at modern retail segment \\
\hline \hline
\end{tabular}

Table 3: Parameter Values

\subsection{Experiment: Model's Predictions for Mexico}

I now simulate the model's predictions when income is set to resemble the Mexican income distribution. Specifically, I first lower $\phi_{\eta}$ to match the human capital level of Mexico relative to the United States, which is $54 \%$ according to Hall and Jones (1999). Second, I lower $\sigma_{\eta}$ to match the standard deviation of the Mexican income distribution, which is $\$ 40,731$. Third, I lower $E$ so that the average wage corresponds to that of Mexico in 2000 , which is $\$ 15,987$. This requires lowering $E$ to 0.43 . I then re-solve the model leaving all other parameter choices the same. ${ }^{16}$

Table 4 presents the results of the experiment. The first row contains the predicted and actual modern retail employment shares $(\mu)$, which are the main object of interest in the experiment. The model predicts a sizeable drop from 0.67 in the United States to 0.39 in Mexico, compared to 0.23 in the Mexican data. This represents $64 \%$ of the United States-Mexico gap in modern retail employment shares, suggesting that the theory is quantitatively important in explaining retail compositional differences. Still, the remaining gap between the model and the data is large, suggesting an important role for other factors in limiting modern store diffusion in Mexico.

As shown in the second row, the model predicts that Mexico's retail-sector output per worker

\footnotetext{
${ }^{16}$ An alternative experiment lowers $E$ to match the average wage in Mexico, keeping the human capital distribution unchanged. Results for modern store shares are similar in this experiment, but overall Mexican retail productivity is too low compared to the data, which is why I prefer the current experiment. Details are available on request.
} 


\begin{tabular}{|c|c|c|c|c|}
\hline \multirow[t]{2}{*}{ VARIABLE } & \multicolumn{2}{|c|}{ UNITED STATES, 2000} & \multicolumn{2}{|c|}{ MEXICO, 2000} \\
\hline & MODEL & DATA & MODEL & DATA \\
\hline MODERN RETAIL SHARE $(\mu)$ & 0.67 & 0.67 & 0.39 & 0.23 \\
\hline Retail-Sector Productivity $\left(Y_{R} / N_{R}\right)$ & 1.00 & 1.00 & 0.32 & 0.30 \\
\hline Auto OWNERShIP RATE & 0.91 & 0.91 & 0.37 & 0.32 \\
\hline $\begin{array}{l}\text { RETAIL-SECTOR EMPLOYMENT } \\
\text { SHARE IN AGGREGATE }\end{array}$ & 0.14 & 0.14 & 0.18 & 0.16 \\
\hline
\end{tabular}

Table 4: Experiment: Model's Predictions for Mexico

$\left(Y_{R} / N_{R}\right)$ is $32 \%$ of the U. S. level. This is quite close to the $30 \%$ value documented in the data (in Section 2 of the paper). This prediction is the result of two forces: the exogenous lowering of $E$ to $43 \%$ of the U.S. value and the endogenous prediction that $\mu$ drops from 0.67 to 0.39 . The endogenous drop in modern store shares by itself leads to $24 \%$ lower retail-sector productivity, or around one-third of the measured productivity gap between Mexico and the United States.

The final two rows show two other important predictions of the model: the percentage of households owning cars and the share of aggregate employment in retail trade. The model produces an elasticity of car ownership to income that is similar to its empirical counterpart in Mexico, with the model predicting 37\% car ownership compared to 32\% in the data. For retail's share of aggregate employment, the model predicts an increase from $14 \%$ in the United States to $18 \%$ in Mexico, whereas in the Mexican data, retail trade represents $16 \%$ of total employment. The model gets the right sign, but predicts too large of an increase in the retail-sector size. I conjecture that incorporating more realistic relative sector productivity changes would improve the model's fit in this dimension.

\subsection{Model's Predictions for Shopping Time and Store Prices}

I now assess the model's predictions for average shopping time and relative prices at modern and traditional stores. Assessing these two predictions is worthwhile since the model's main trad-eoff is one of lower prices versus higher shopping time at modern stores. I find that the model's predictions are quantitatively in line with the available evidence.

The model predicts that shopping time should be $4 \%$ lower in Mexico than in the United States. This is accounted for by fewer model households shopping at relatively time-intensive modern 
stores. Although the United States and Mexico have both conducted time surveys, the questions and methodology differ in the two countries, which makes comparisons difficult. The two internationally comparable time use surveys of which I am aware are the Multi National Time Use Survey (MNTUS) and the Harmonised European Time Use Survey (HETUS). Allesandria and Kaboski (2007) use these two surveys to study the link between average shopping time and average income in the cross-section of countries. In both surveys they find a positive relationship between income per capita and average time spent shopping. According to their estimates, a 77\% drop in income (corresponding to the drop in my experiment) is associated with a drop in average shopping time of $15 \%$, with a $90 \%$ confidence interval of between a $1 \%$ drop and a $28 \%$ drop..$^{17}$ I conclude that the model's shopping time predictions are quantitatively consistent with the international correlation between average shopping time and per capita income level.

The model's predictions for relative prices in the two segments are in the range suggested by the data as well. In the model, the price at modern stores is $18 \%$ lower than the price at traditional stores. For the United States, Hausman and Leibtag (2005) analyze data on prices paid by households for a set of 20 food items at two types of retailers: traditional supermarkets, and a second category which consists of "supercenters, mass merchandisers, and club stores." They find that prices in the latter "modern" category ranged from $5 \%$ to $48 \%$ lower than in the traditional category. Basker (2005) cites evidence that Wal-Mart prices are in the range of $17 \%$ to $39 \%$ lower than competing grocery stores. Internationally, the most direct evidence comes from the McKinsey Global Institute. For a set of comparable goods in Mexico, McKinsey reports that prices in traditional stores were between $5 \%$ and $15 \%$ higher than in modern stores. For Brazil, they report up to $30 \%$ higher prices in traditional stores; in Poland prices are between $10 \%$ to $30 \%$ higher; in Thailand on average $21 \%$ higher; and in Turkey, up to $30 \%$ higher.

\subsection{What Disciplines the Quantitative Results?}

The results thus far have shown that the model produces quantitatively large effects of income on modern retail shares. What drives these quantitative predictions? Intuitively, the elasticity of the modern retail share to income is driven by two components: the elasticity of car ownership to income, and the difference in the probability of shopping at the modern store between car owners and non-car owners. The discipline on the former comes from the model's matching the car ownership in the United States, where all but the poorest households own cars. I also showed above that the model's elasticity is in line with the empirical elasticity implied by the United States and Mexican data.

The conditional probability of shopping at a modern store for car owners and non-car owners

\footnotetext{
${ }^{17}$ From the HETUS, they estimate a coefficient of log shopping time on log GDP per capita of 0.198 with a $t$-statistic of 2.83, and from the MTUS their estimate is 0.208 with a $t$-statistic of 3.10 .
} 
is disciplined as follows. The parameterized model matches the unconditional probabilities of shopping at a modern store and owning a car, and the conditional probability that a given shopper at a modern store is a car owner. The conditional probabilities of shopping at a modern store given car ownership (and not) follow by Bayes' rule. Intuitively, the fact that the fraction of modern-store shoppers that are car owners is higher than the fraction of all households that are car owners tells us that households are more likely to shop at modern stores if they have a car. The difference between these two fractions pins down how much more likely a car owner is to shop at modern stores than a non-car owner.

The model's conditional probabilities of shopping at a modern store are $86 \%$ for car owners and 30\% for non-car owners. Unfortunately, few direct estimates of these probabilities exist. The one study I was able to find (by Bromley and Thomas, 1993) uses survey evidence from the town of Swansea in the United Kingdom to document that "between $71 \%$ and $86 \%$ of car owners patronized a superstore for their food shopping; for the carless the percentages vary between $31 \%$ and $57 \% . "$ These estimates are very much in line with the model's values.

\section{Policies that Distort the Market for Cars}

Thus far, I have argued that retail technology choice is largely optimal in poor countries given their low income. In this section, I argue that an additional channel accounting for low retail productivity is government policies that distort the market for cars. These policies, which distort household decisions, have received little attention in the literature on aggregate productivity differences, which typically focus on distortions to producers.

Numerous well-known distortions can be found in the market for cars. In the developing world, tariffs on new car imports are common, as are taxes on new car purchases regardless of where the car is manufactured. Brazil is a particularly apt example. Because Brazil is a member of the Mercosur regional trade union, non-member countries face a tariff of $35 \%$ to import a car into Brazil. For any new car purchase, buyers must pay three different sales taxes, which total from $27 \%$ to $36 \%$ of the retail price (depending on the vehicle type). In addition, anyone operating a car in Brazil must pay an additional tax each year totaling from $1 \%$ to $6 \%$ of the vehicle's value, depending on the operator's state of residence. ${ }^{18}$ Removing or reducing taxes of this kind is likely to lead to substantial reductions in auto prices and increased car ownership.

One perhaps lesser-known policy that a large number of developing countries share is the restriction of imports of used autos. Policies of this sort typically come in the form of outright bans on used-car imports, prohibitive tariffs, and limitations on the age of used vehicles that can

\footnotetext{
${ }^{18}$ See the Brazilian Automotive Industry (ANFAVEA) Yearbook for 2008.
} 
be imported. Pelletiere and Reinert (2002) document the extent of used-vehicle import restrictions in a large number of developed and developing countries and find that these restrictions are widespread and often severe. They found evidence that in 19 developing countries there are complete prohibitions on importing a used car. In another 27 countries there are other "substantial restrictions" of various kinds. ${ }^{19}$ Restrictions on used-car imports might be an important reason for the low rate of car ownership and low measured retail productivity in developing countries.

\subsection{Evidence from Cyprus}

Because so few countries have enacted and then repealed bans on used-car imports, there is no systematic evidence on how much repealing these bans would affect domestic car markets. Fortunately, there is one historical episode that can shed light on the issue, occurring in Cyprus in the 1990s.

Clerides (2008) documents that Cyprus greatly repealed its limitations on the imports of used cars in 1993. Because this policy change occurred largely independently of other changes in the regulatory and economic environment, Clerides argues that the Cypriot experience provides a case study in which to learn about the effects of repealing used-car import bans. He finds that after the restrictions were repealed, there was a substantial expansion in the overall car market led by large increases in used-car imports (almost all from Japan). In 1992, while the bans were still in place, just 7\% of all first-time car registrations in Cyprus were imported used cars. In 1998, after the ban was repealed, this figure skyrocketed to $72 \%$ of all first-time registrations. Perhaps not surprisingly, prices of the used-car imports were substantially lower than new cars sold of the same make and model.

My theory predicts that this expansion in the Cypriot car market should have been accompanied by an expansion in modern retailing. To help assess this prediction, I collected data on the share of employment at modern stores and the number of large chain supermarkets in Cyprus around the time of the car market liberalization. ${ }^{20}$ Figure 6 shows the number of used cars sold in Cyprus over this period (bars), the fraction of retail workers at stores with 20 or more workers (dots), and the number of supermarket stores at the largest five chains in Cyprus (solid line). A few years after 1993 the drastic increase in sales of used cars is clearly visible. The modern-store employment share, which unfortunately is not available in all years, rises from around $12 \%$ in the early 1990 s to around $25 \%$ by 2001 . Corroborating these official data is the expansion of

\footnotetext{
${ }^{19}$ As of 1999, there were complete bans on used-car imports in Argentina, Algeria, Brazil, Chile, China, Colombia, Ecuador, Egypt, India, Indonesia, Mexico, Pakistan, Paraguay, the Philippines, South Korea, Thailand, Turkey, Uruguay, and Vietnam.

${ }^{20}$ The official Cypriot retail statistics are publicly available from the Cyprus Department of Statistics and Research of the Ministry of Finance. I obtained the chain supermarket data from the stores themselves.
} 
the largest Cypriot supermarket chains over this period, which roughly tripled the number of stores.

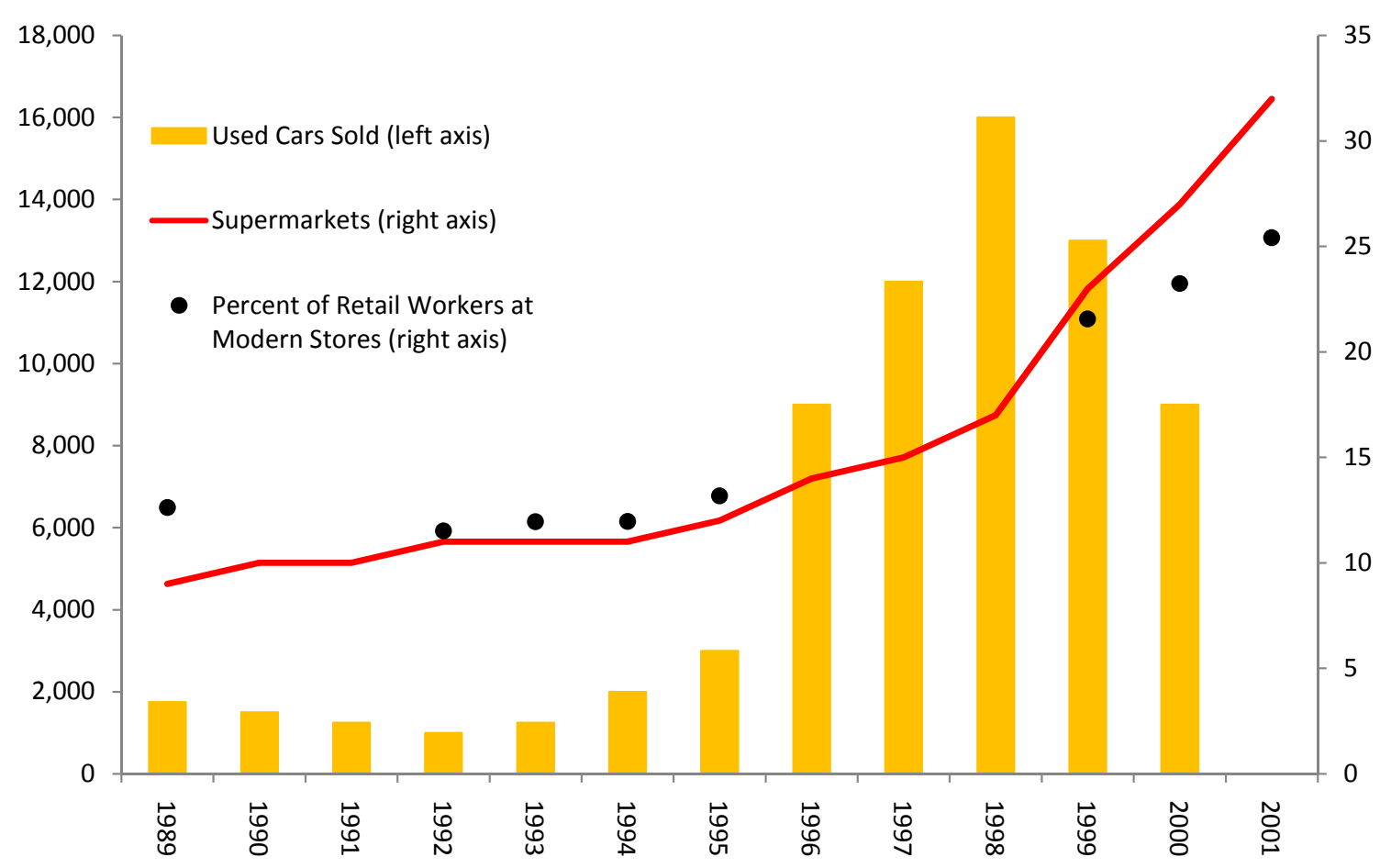

Figure 6: Used Car Sales and Modern Store Prevalence in Cyprus

Although there are likely to have been other changes in Cyprus around this period that could account for the rise in modern retailing, the most obvious other candidate, a dramatic rise in income, does not seem to be supported in the data. According to the Penn World Tables, real GDP growth was similar in the five-year period after 1993 as the five years before, with an average growth rate of $5.4 \%$ per year before and $4.6 \%$ after. I conclude that the experience of Cyprus is broadly consistent with my theory. This case also yields support to the idea that repealing bans on importing used cars could be important in increasing car ownership and retail productivity in other nations.

\subsection{Model Experiment}

I now use the model to gauge the potential quantitative impacts of removing distortions in the car market on the modern retail share and labor productivity in the retail sector. I do this by decreasing auto prices in the model by $10 \%, 15 \%$, and $20 \%$, which I consider plausible given the evidence presented in the previous section. I find that these impacts could be sizeable. 


\begin{tabular}{|c|c|c|c|}
\hline $\begin{array}{l}\text { CAR PRICE } \\
\text { REDUCTION }\end{array}$ & $\begin{array}{c}\text { MODERN EMPLOYMENT } \\
\text { SHARE }\end{array}$ & $\begin{array}{c}\text { CAR OWNERSHIP } \\
\text { RATE }\end{array}$ & $\begin{array}{l}\text { PRODUCTIVITY } \\
\text { GAINS }\end{array}$ \\
\hline $\begin{array}{c}0 \% \\
-10 \% \\
-15 \% \\
-20 \%\end{array}$ & $\begin{array}{l}0.39 \\
0.43 \\
0.46 \\
0.48\end{array}$ & $\begin{array}{l}0.36 \\
0.41 \\
0.44 \\
0.47\end{array}$ & $\begin{array}{c}- \\
+5.5 \% \\
+7.5 \% \\
+10.4 \%\end{array}$ \\
\hline
\end{tabular}

Table 5: Experiment: Removal of Distortions in Car Markets

The results of the experiment are presented in Table 5. The model predicts that car price drops are associated with increases in car ownership up from $36 \%$ to $47 \%$ of all households. The associated increases in the modern employment share are up from 0.39 to 0.48 , and the resulting productivity gains are as high as $10.4 \%$. How realistic is the model's prediction for auto ownership elasticities to market prices? The model predicts an elasticity of around -1.4. McCarthy (1996) surveys estimates of the market price elasticity of demand for cars and finds a range of -0.6 to -1.2 , suggesting that the model is in the right ballpark as the available econometric evidence. I conclude that distortions in the car market could be a quantitatively important factor in explaining the limited diffusion of modern stores and low retail-sector productivity in poor countries.

\section{Conclusion}

I document that measured productivity differences in retail trade between the United States and a set of developing countries are accounted for in large part by differences in the composition of retail technologies used. Modern stores, with high measured output per worker, are used widely in richer countries, whereas low-productivity traditional stores are most prevalent in the developing world.

Unlike most theories of productivity differences, which emphasize barriers to technology adoption or inefficient production arrangements, retail productivity differences, in my view, largely reflect optimal behavior in developing countries. Because general efficiency (and the wage level) is low in developing countries, households purchase fewer cars and other household durables that reduce shopping time. As a result, entrepreneurs rationally deploy few modern retail stores, which are shopping-time intensive. I support the theory using new disaggregated evidence for a set of developing countries, and with a quantitative analysis of a simple model of home production and retail technology adoption. 
One implication of the paper is that policies which lead to inefficient production in one sector of the economy might help account for low measured productivity in other sectors. This could apply to other non-tradeable services for which frontier technologies require a large scale of operations, and for which low household transportation costs are important. Government investment in transportation infrastructure is one commonly mentioned way to reduce household transportation costs. I argue that another way is for governments to reduce distortions on car ownership by households.

Finally, the paper suggests that a broader fraction of household capital and labor than previously thought are inputs to production, and hence that some household inputs are missing from current productivity measures. In the retail trade sector, household shopping time and capital goods used for transportation and storage, such as cars, are important components in the widespread adoption of modern stores. More broadly, what might appear to be more efficient production in developed countries may in fact be explained (in part) by households in these countries providing more inputs into production.

\section{A Data Appendix}

\section{Censuses of Retail Trade}

As described in Section 2, the census data that I employ come from every developing country (those with less than one-half the U. S. income per capita) in which a census of retail trade has been conducted in the last 10 years, and for which comparable data exist. The four compatibility criteria are as follows. First, the data must have allowed me to isolate retail trade from wholesale trade. Second, the census must not have excluded establishments below a certain size. Third, the data must have reported inputs and outputs by size category of store. Fourth, the labor input data must have included unpaid workers as well as paid, since unpaid work is prevalent in retailing. The censuses satisfying these criteria are as follows.

Brazil - Data come from the 2002 Pesquisa Anual de Comércio conducted by the Instituto Brasileiro de Geografía e Estatística,

(http://www.ibge.gov.br/home/estatistica/economia/comercioeservico/pac/2005/default.shtm).

El Salvador — Data come from the 2005 Censo Económico, Comércio:

(http://www.digestyc.gob.sv/).

Mexico - Data come from the 2005 Censo Económico conducted by the Instituto Nacional de Estadistíca, Geografía e Informática (www.inegi.gob.mx/). Capital value is the reported book value of land, structures, and equipment used for production exclusively by the establishment. 
Philippines - Data come from the 2005 Annual Survey of Philippine Business and Industry conducted by the Philippine National Statistics Office (http://www.census.gov.ph/)

Thailand - Data come from the 2002 Business Trade and Services Survey conducted by the National Statistical Office of Thailand (http://web.nso.go.th/).

United States - Data come from the BEA GDP-by-Industry Accounts. The underlying source of the data is the Economic Census, conducted every five years by the Bureau of the Census. For comparability with other countries, I use total full-time and part-time employees as my measure of labor input.

\section{Evidence that Labor Productivity Reflects TFP}

In this section, I ask whether labor productivity differences between modern stores and traditional stores can be explained by differences in capital per worker. Using data from Mexico, where book value of capital (including land) is collected, I find that they are not. These findings suggest that labor productivity measures used in this paper largely reflect TFP differences.

To measure TFP, I posit a Cobb-Douglas production function for the composite retail service, specifically, $Y_{j}=\min \left[T F P_{j} \cdot L^{\gamma} \cdot K^{1-\gamma}, X\right]$, where $K$ is capital equipment, structures, and land; $T F P_{j}$ is total factor productivity in technology (segment) type $j$; and $\gamma$ is the labor share in technology $j$. The ratio of TFP in modern to traditional segments can then be written using an expression analogous to 2 .

For the labor share parameter $\gamma$, I consider a range of values, namely, 0.5, 0.6, and 0.7. The value 0.5 corresponds to the ratio of payments to workers over value added for the modern stores. A similar calculation for traditional stores is unlikely to be informative, however, since such a large fraction of workers at smaller retail establishments are unpaid. Thus I consider 0.6 and 0.7 as two plausible larger values. Note that higher values of $\gamma$ will tend to increase the measured ratio of modern TFP to traditional TFP. Thus, this range should be thought of as bounding relative TFP below.

Table 6 presents the TFP ratios I calculated for Mexico. The first data column shows that relative TFP is between 2.4 and 2.9 times higher in modern stores than in traditional ones, depending on the labor share assumed. The second data column shows the relative TFP ratio as a fraction of the relative labor productivity ratio. The fraction of the output per worker ratios accounted for by TFP is between $65 \%$ and $77 \%$, suggesting that output per worker largely reflects TFP. 


\begin{tabular}{c|c|c}
\hline \hline LABOR SHARE & MODERN/TRADITIONAL RELATIVE TFP & RELATIVE TFP OVER RELATIVE Y / L \\
$\gamma$ & $T F P_{M} / T F P_{T}$ & $\frac{T F P_{M} / T F P_{T}}{\frac{Y_{M} / Y_{T}}{N_{M}}}$ \\
\hline 0.5 & 2.4 & 0.65 \\
0.6 & 2.6 & 0.71 \\
0.7 & 2.9 & 0.77 \\
\hline \hline
\end{tabular}

Table 6: Ratio of TFP in Modern and Traditional Retailing, Mexico.

\section{Corroborating Evidence from McKinsey Productivity Studies}

In this section, I provide some corroborating evidence from the McKinsey Productivity Studies, which were conducted independently using different methods and a different set of countries. The key differences from my empirical work is that I use publicly available census data, whereas McKinsey uses their own (smaller) samples of establishments, and I use a size-based definition of a "modern" retail establishment, whereas they use a more descriptive definition. Martin Baily and Robert Solow, who were both collaborators in the McKinsey studies, offer an overview of the McKinsey findings and a more detailed description of their methods (Baily and Solow, 2001).

In their study of cross-country differences in retailing, McKinsey obtained store-level data on labor inputs, sales, and the cost of goods purchased for re-sale using surveys of stores designed with the help of the economists who served as consultants. The productivity measure used in the McKinsey studies is value added per worker, where labor input is measured as total hours worked by paid and unpaid workers. To allow direct comparisons with the United States, productivity measures are deflated using PPP exchange rates for consumption goods, or for food when the focus is specifically on the food retail sector. McKinsey computes labor productivity for two types of retailers: "traditional" and "modern," which cover all establishments in the industry. Modern stores are typically (depending on the country) made up of hypermarkets, supermarkets, convenience stores, specialty stores, and department stores. Traditional stores typically are defined to be street vendors, open-air markets, and counter stores.

Despite our differences, the McKinsey findings paint a picture similar to mine. Table 7 displays value added per worker and employment shares for their set of developing countries studied: Brazil, Poland, Russia, Thailand, and Turkey, as well as the United States. The table confirms each of the results put forth in the previous section. First, retail-sector productivity 


\begin{tabular}{|c|c|c|c|c|}
\hline COUNTRY & $\begin{array}{r}\text { Labo } \\
\text { Retail Sector }\end{array}$ & PRODUCT & $\begin{array}{l}\text { VITY } \\
\text { TRADITIONAL }\end{array}$ & $\begin{array}{c}\text { MODERN } \\
\text { EMPLOYMENT } \\
\text { SHARE }\end{array}$ \\
\hline Brazil, Food Retail (1996) & 14 & 51 & 11 & 7 \\
\hline Poland (1999) & 24 & 83 & 18 & 8 \\
\hline Russia, Food Retail (1995) & 23 & 78 & 22 & 1 \\
\hline Thailand (2001) & 22 & 107 & 13 & 10 \\
\hline Turkey (2001) & 29 & 72 & 22 & 12 \\
\hline United States (2001) & 100 & 118 & 32 & 79 \\
\hline
\end{tabular}

Note: VA/L in United States retail sector is normalized to 100.

Table 7: McKinsey Productivity Studies Findings for Retail in Developing Countries.

is low compared to that of the United States, at around $14 \%$ to $29 \%$ of the United States level. Second, productivity shows up as being substantially higher in modern establishments than in traditional ones, with a factor of 4 to 5 separating them, including the United States. Third, the employment shares in modern stores are low in the developing countries (12\% or less) and high in the United States (79\%).

\section{B Other Theories of Retail Composition Differences}

In this section, I discuss other potential reasons why developing countries have a mix of retail establishments with relatively fewer modern stores.

One obvious candidate reason is that entry of modern stores is blocked directly through government policy. This is the view espoused by Parente and Prescott $(1994,1999)$. The McKinsey studies cite policies that restrict stores above a certain size threshold in Japan and argue that the Indian government indirectly blocks large stores by prohibiting Foreign Direct Investment (FDI) in retail. Guner, Ventura, and Xu (2008) confirm the quantitative significance of the Japanese legislation and present similar evidence of regulation in France, Italy, and Korea. Still, for many other countries, including the set studied in the current paper, laws which directly block large-scale retailers do not seem to be present. In their country reports on the retail trade industry, for example, both Euromonitor International and McKinsey report that laws 
restricting new entry among certain retail format types are not present in Brazil, Mexico, the Philippines, or Thailand. Nor are laws banning FDI present in retailing.

What is more common are claims that large-scale stores are affected indirectly by high tax rates that they are too large to avoid, unlike smaller stores. According to this informality theory of low modern store prevalence, small-scale stores can offer an artificially lower price by evading taxes and other regulations, whereas modern stores cannot. The McKinsey studies claim that informality is one of the main reasons modern stores are so uncommon in emerging markets. One challenge to this theory is that if tax evasion is the main limiting factor for modern operations, then we should see large variation in modern employment shares across countries with different tax rates. For example, Mexico has no value added tax on food, whereas Brazil has value added taxes totaling up to $40 \%$ of the final good price (McKinsey, 1995). As was shown in Figure 3, however, modern stores are equally uncommon in Brazil as Mexico, which is in variance with the tax evasion theory. Still, future exploration of this theory seems worthwhile, given the notorious inability or unwillingness of governments in many developing countries to deter tax evasion.

An alternative theory is that poor countries optimally choose a mix of retailers that is primarily traditional because relatively lower wages in developing countries favor labor-intensive technologies, rather than capital-intensive ones. A counterargument is that mobility of factors within a given developing country should equalize factor prices within the country. If this is true, then one should see that modern store employment shares are similarly low in all districts within a developing country. Yet as I documented in Section 3, there are vast differences in modern store employment shares across districts in Mexico, and there is evidence that this is the case in other developing nations as well. One factor for which prices do not equalize across districts is land: land prices are higher in richer urban areas than in poorer rural areas. Yet, (land-intensive) modern stores are most prevalent in richer areas, as I show, not least prevalent, as would be predicted by this factor-price theory.

\section{Model Appendix}

\section{Condition for $\mu$ to Be Increasing in $E$}

To show that $\mu$ is increasing in $E$, it suffices to prove that $\frac{\partial N_{M}}{\partial E}>\frac{\partial N_{T}}{\partial E}$. Note that $\frac{\partial N_{M}}{\partial E}=\frac{\partial Y_{M}}{\partial E} \cdot \frac{1}{Z_{M}}$ and $\frac{\partial N_{T}}{\partial E}=\frac{\partial Y_{T}}{\partial E} \cdot \frac{1}{Z_{t}}$ by the production function (8). The partial derivatives of $Y_{M}$ and $Y_{T}$ with respect to $E$ can be calculated directly using the market-clearing conditions. The market for 
modern goods clears when

$$
Y_{M}=\int_{0}^{\tilde{\psi}(0)} \int_{0}^{\tilde{\eta}(\psi)} \frac{\eta w \bar{n}}{p_{M}} d G(\eta) d H(\psi)+\int_{0}^{\tilde{\psi}(1)} \int_{\tilde{\eta}(\psi)}^{\infty} \frac{\eta w \bar{n}-p_{a}}{p_{M}} d G(\eta) d H(\psi)
$$

Then $\frac{\partial Y_{M}}{\partial E}$ can be shown to be

$$
\frac{\mathbb{E}(\eta) \bar{n}}{p_{M}} H(\tilde{\psi}(0))-\frac{p_{a}}{p_{M}} \int_{0}^{\tilde{\psi}(0)} \Phi(\psi) d H(\psi)+\int_{\psi(0)}^{\psi \tilde{(1)}} \frac{\bar{n} \mathbb{E}(\eta \mid \eta>\tilde{\eta}(\psi))-p_{a}}{p_{M}}+\frac{E \bar{n} \tilde{\eta}(\psi)}{p_{M}} \Phi(\psi) d H(\psi),
$$

where $\Phi(\psi) \equiv g(\tilde{\eta}(\psi)) \frac{-\partial \tilde{\eta}}{\partial E}$ and represents the marginal increase in the measure of flexible households shopping at modern stores. The first and third terms are positive and represent the gain in quantity sold at modern stores due to an $E$ increase by modern-only and flexible households. The second term is negative and represents the decrease in quantity purchased at modern stores by modern-only households due to a car purchase (and a diversion $p_{a}$ of their income from purchases at $M$ ).

Intuitively, $\frac{\partial N_{M}}{\partial E}>\frac{\partial N_{T}}{\partial E}$ when the price of a car is small relative to average income, thus guaranteeing that this negative term is sufficiently small. Formally, rewriting the condition $\frac{\partial Y_{M}}{\partial E}-\frac{\partial Y_{T}}{\partial E}>$ 0 and rearranging terms yields this condition:

$$
p_{a}<\frac{\mathbb{E}(\eta) \bar{n}\left(\frac{H(\tilde{\psi}(0))}{1+Z_{M}}+\frac{1-H(\tilde{\psi}(1))}{1+Z_{T}}\right)+\bar{n} \int_{\psi(0)}^{\psi(\tilde{(1)})} \frac{\mathbb{E}(\eta \mid \eta>\tilde{\eta}(\psi))+E \Phi(\psi)}{1+Z_{M}}-\frac{\mathbb{E}(\eta \mid \eta \leq \tilde{\eta}(\psi))+E \Phi(\psi)}{1+Z_{T}} d H(\psi)}{\frac{1}{1+Z_{M}} \int_{0}^{\tilde{\psi}(1)} \Phi(\psi) d H(\psi)-\frac{1}{1+Z_{T}} \int_{\tilde{\psi}(1)}^{\infty} \Phi(\psi) d H(\psi)} .
$$

\section{Parameterizing the Model}

In this section, I provide a more thorough description of how the values for the model's parameters are chosen. Six of the values are pinned down directly. These are $E$, normalized to $1, \bar{n}$, set to $1 / 3, \phi_{\eta}$ and $\sigma_{\eta}$ to match the mean and variance of the United States household income distribution, $\gamma$, described below, and $\bar{A}$, set to match a $\$ 5,481$ annual cost of purchasing and operating a car. This is the American Automobile Association's (AAA) calculation for the average cost of operating a car for one year for a total of 10,000 miles, including insurance, license, registration, taxes, gasoline, and maintenance (see the AAA 2007 booklet Your Driving Costs, published annually).

For $\gamma$, I choose a value of 0.66 , which I set as follows. I assume that owning the car saves shopping time in two ways. First, it reduces the travel time per shopping trip, and second, it reduces the number of shopping trips (because the household can buy in bulk). Assuming that 
total shopping time satisfies

total shopping time $=\#$ of trips $\times($ in-store time per trip + traveling time per trip $)$

one can back out the total time savings of owning a car by computing (1) the travel time reduction of a car over public transportation, (2) the reduction in number of trips with a car over public transportation, and (3) the fraction of per tip shopping time consisting of traveling.

To compute travel time savings, I use data on commuting time, which is widely studied. Using a large national survey of U.S. households, the 2001 National Household Travel Survey (NHTS), the U.S. Department of Transportation computes that an average commute by private automobile covered 35.2 miles per hour, whereas an average commute by public transport covered 19.6 miles per hour. This implies that public transport is $55.6 \%$ as fast as travel by car for a given commuting trip. For the fraction of shopping time that represents travel, I compute, using the 2003 ATUS, that travel is exactly 50\% of total shopping time. Finally, for trip reductions by car, the NHTS reports that $86 \%$ as many shopping trips are taken with a car as with public transportation. I assume this reflects the car's advantage in economizing on the number of shopping trips. Putting these numbers together, we see that the shopping time with a car is a fraction $0.86 \times(0.5 \times 1+0.5 \times 0.556)=0.66$ of shopping time without a car.

The values of the remaining seven parameters are jointly determined using seven moments from the data. For expositional purposes, I explain the choice of each parameter along with a target in the data which, in my opinion, most closely describes the parameter's identification. I choose $\phi_{\psi}$, the first moment of the leisure time value distribution, to match the U.S. modern retail employment share of 0.67, as documented in Section 2. For $\sigma_{\psi}$, I choose a value consistent with the probability that a household shopping at a modern store comes via car (as opposed to public transport or on foot). A study of the shopping patterns of 60,000 households in the Quebec metropolitan area in 2001 (by Biba et al, 2006) reports that 96.7\% of patrons at modern retail establishments came via car. Using these targets, the resulting time value distribution has parameters $\phi_{\psi}=1.864$ and $\sigma_{\psi}=0.290$.

Next, I turn to the relative shopping costs at modern and traditional stores, $\nu_{M}$ and $\nu_{T}$, and the car taste parameter $\alpha$. Using the 2003 ATUS, I find that the average weekly time spent shopping for consumer goods by households with cars and households without cars are 5.8 hours and 3.2 hours, respectively. By setting shopping times in the model to match these two averages, I pin down $\nu_{M}$ and $\nu_{T}$. The taste parameter for cars, $\alpha$, is pinned down to give a $91 \%$ car ownership rate, which I calculate using the 2000 Census to be the fraction of U.S. households with at least one car. The resulting values are $\nu_{M}=0.036, \nu_{T}=0.014$, and $\alpha=0.505$.

Finally, for the production side of the economy, I pick $Z_{T}$ to get $14 \%$ of total employment in the retail sector, which is the 2000 value for the United States according to the BEA. Using 
the calculations of Section 2.4, I pick $Z_{M}$ to get a relative productivity of 3 in modern stores over traditional stores, which is a conservative value given the measurements of Section 2 . The parameterized values are $Z_{T}=2.62$ and $Z_{M}=7.86$.

\section{References}

Acemoglu, Daron, and Fabrizio Zilibotti. 2001. "Productivity Differences." Quarterly Journal of Economics 116 (2): 563-606 (May).

Allesandria, George, and Joseph Kaboski. 2007, September. "Pricing to Market and the Failure of Absolute PPP." FRB of Philadelphia Working Paper No. 07-29.

Baily, Martin Neil, and Robert M. Solow. 2001. "International Productivity Comparisons Built from the Firm Level." Journal of Economic Perspectives 15 (3): 151-172.

Basker, Emek. 2005. "Selling a Cheaper Mousetrap: Wal-Mart's Effect on Retail Prices." Journal of Urban Economics 58 (2): 203-299 (September).

Becker, Gary S. 1965. “A Theory of the Allocation of Time." Economic Journal 75 (299): 493-517.

Benhabib, Jess, Richard Rogerson, and Randall Wright. 1991. "Homework in Macroeconomics: Household Production and Aggregate Fluctuations." Journal of Political Economy 99 (6): 1166-1187 (December).

Biba, Gjin, Francois Des Rosiers Marius Theriault, and Paul Villeneuve. 2006. "Big Boxes versus Traditional Shopping Centers: Looking at Households' Shopping Trip Patterns." Journal of Real Estate Literature 14 (2): 175-202.

Bosworth, Barry P., and Jack E. Triplett. 2004. Productivity in the US Services Sector: New Sources of Economic Growth. Brookings Institution Press.

Bromley, Rosemary D. F. 1998. "Market-place Trading and the Transformation of Retail Space in the Expanding Latin American City." In Retailing: Critical Concepts, edited by Anne M. Findlay and Leigh Sparks, Volume IV. Routledge.

Bromley, Rosemary D. F., and Colin J. Thomas. 1993. "The Retail Revolution, the Car-less Shopper, and Disadvantage." In Retailing: Critical Concepts, edited by Anne M. Findlay and Leigh Sparks, Volume IV. Routledge.

Buera, Francisco J., and Joseph P. Kaboski. 2007, August. "The Rise of the Service Economy." http:/ / faculty.wcas.northwestern.edu/ fjb913/services.pdf.

Caselli, Francesco, and Wilbur John Coleman II. 2006. "The World Technology Frontier." American Economic Review 96 (3): 499-522 (June). 
Clark, Gregory. 1987. "Why Isn't the Whole World Developed? Lessons from the Cotton Mills." Journal of Economic History 47 (March): 141-173.

Clerides, Sofronis K. 2008. "Gains from Trade in Used Goods: Evidence from the Global Market for Automobiles." Journal of International Economics 76 (2): 322-336 (December).

Euromonitor International. Country Market Insight Reports, Retailing: Mexico (2008), Brazil (2008), the Philippines (2008), Thailand (2008).

Foster, Lucia, John Haltiwanger, and C. J. Krizan. 2006. "Market Selection, Reallocation and Restructuring in the U.S. Retail Trade Sector in the 1990s." Review of Economics and Statistics 88 (November): 748-758.

Fuchs, Victor R. 1969. The Service Economy. New York: Columbia University Press/NBER.

Goldman, Arieh. 2000. "Supermarkets in China: the case of Shanghai." In Retailing: Critical Concepts, edited by Anne M. Findlay and Leigh Sparks, Volume IV. Routledge.

Greenwood, Jeremy, Ananth Seshadri, and Mehmet Yorukoglu. 2005. "Engines of Liberation." Review of Economic Studies 79 (1): 109-133.

Guner, Nezih, Gustavo Ventura, and Daniel Xu. 2008. "Macroeconomic Implications of SizeDependent Policies." Review of Economic Dynamics 11 (4): 721-744 (October).

Hall, Robert E., and Charles I. Jones. 1999. "Why Do Some Countries Produce So Much More Output per Worker than Others?" Quarterly Journal of Economics 114 (1): 83-116 (February). Hausman, Jerry, and Ephraim Leibtag. 2005. "Consumer Benefits from Increased Competition in Shopping Outlets: Measuring the Effect of Wal-Mart." NBER Working Paper 11809.

Herrendorf, Berthold, and Arilton Teixeira. 2009, January. "Barriers to Entry and Development." http://www.public.asu.edu/ bherrend/Unpublished\%20Papers/IER1.pdf.

Hsieh, Chang-Tai, and Peter J. Klenow. 2009. "Misallocation and Manufacturing TFP in China and India." Quarterly Journal of Economics. Forthcoming.

Jones, Charles I. 2009, January. "Intermediate Goods and Weak Links: A Theory of Economic Development." http://www.stanford.edu/ chadj/links300.pdf.

Klenow, Peter J., and Andrés Rodríguez-Clare. 1997. "The Neoclassical Revival in Growth Economics: Has it Gone Too Far?" In NBER Macroeconomics Annual 1997, edited by Ben S. Bernanke and Julio Rotemberg. Cambridge, MA: MIT Press.

Kopecky, Karen A., and Richard M. H. Suen. 2009, January. "A Quantitative Analysis of Suburbanization and the Diffusion of the Automobile." http://www.karenkopecky.net/SandAPaper.pdf.

Lagakos, David. 2008, June. "Essays on Productivity and Macroeconomics." Ph.D. diss., UCLA. 
McCarthy, Patrick S. 1996. "Market Price and Income Elasticities of New Vehicle Demands." Review of Economics and Statistics 78 (3): 543-547.

McKinsey Global Institute. Turkey, Retail Trade (2001), Brazil, Food Retail 1995), Russia, Food Retail (1996), India, Retail (1997), Thailand, Retail Trade (1999), Poland, General Merchandise Retailing (1999), New Horizons: Multinational Company Investment in Developing Economies: Food Retail Sector (2003). http://www.mckinsey.com/mgi/rp/CSProductivity/.

Minnesota Population Center. 2006. “Integrated Public Use Microdata Series-International: Version 2.0." Minneapolis: University of Minnesota.

Oi, Walter Y. 1992. "Productivity in the Distributive Trades: The Shopper and the Economies of Massed Reserves." Chapter 4 of Output Measurement in the Service Sectors, edited by Zvi Griliches. Chicago: University of Chicago Press/NBER.

Parente, Stephen L., and Edward C. Prescott. 1994. “Barriers to Technology Adoption and Development." Journal of Political Economy 102 (2): 298-321.

—. 1999. "Monopoly Rights: A Barrier to Riches." American Economic Review 89 (5): 1216-1233 (December).

Parente, Stephen L., Richard Rogerson, and Randall Wright. 2000. "Homework in Development Economics: Household Production and the Wealth of Nations." Journal of Political Economy 108 (4): 680-687 (August).

Pelletiere, Danilo, and Kenneth A. Reinert. 2002. "The Political Economy of Used Automobile Protection in Latin America." World Economy 25 (August): 1019-1037.

Prescott, Edward C. 1998. "Needed: A Theory of Total Factor Productivity." International Economic Review 39 (3): 525-551.

Restuccia, Diego, and Richard Rogerson. 2008. "Policy Distortions and Aggregate Productivity with Heterogeneous Establishments." Review of Economic Dynamics 11 (4): 707-720 (October).

Schmitz, James A. Jr. 2005. "What Determines Productivity? Lessons from the Dramatic Recovery of the U.S. and Canadian Iron Ore Industries Following Their Early 1980s Crisis." Journal of Political Economy 113 (3): 582-625 (June).

U.S. Department of Transportation, Federal Highway Association. 2004, December. Summary of Travel Trends: 2001 National Household Travel Survey. http://nhts.ornl.gov/2001/pub/STT.pdf. 